\title{
Inovasi Pembelajaran Pantun Berbasis Kearifan Lokal
}

\author{
Abdul Rahman Rahim ${ }^{1^{*}}$, Wardiman ${ }^{2}$, Yuni Lestari ${ }^{3}$ \\ Universitas Muhammadiyah Makassar, Jln. Sultan Alauddin No. 259 Makassar, \\ *Corresponding Email: rahman@unismuh.ac.id
}

\begin{abstract}
Pantun is a type of old poem that is written and usually uses a tone or song. Pantun consists of the elements of a sentence of four lines in a verse, which is based (a-b-a-b). Usually the first row and the second row are sampiran, the third and fourth rows are the contents. This research aims to test the effectiveness of an innovation of learning based on local wisdom pantun namely by using a dictionary of courses. This research is categorized into experimental research types. The method used by researchers in this study is quasi experiment with one group pretest posttest design model. The population is all students of class V sdn 331 Borongtellutahun 2020/2021. The population numbered 30 people as well as a sample of the study. This study uses tests to find out the ability to write the student guide The test is given twice, namely pre-action and post-action. The data in this study were analyzed using statistical techniques inference design analysis, simple linear regression. Based on the results of this study, it can be concluded that the results of learning to write pantun students of grade V SD Negeri 331 Borongtellu using conventional techniques is an average of 67.74 in the range of 10-100 grades with a moderate category. After being treated using rhyming dictionaries and lateral thinking, the student's learning outcomes averaged 79.33in the range of grades 10-10o with a high category. Thus the use of rhyming dictionaries and lateral thinking effective in improving the results of writing local wisdom-based pantun learning in grade $V$ students of SD Negeri 331 Borongtellu, because the t-count /empirical value is greater than the table/theoretical t-value (14.27>1.6709).
\end{abstract}

Keywords

pantun, rhyme dictionary, local wisdom

\begin{abstract}
Abstrak
Pantun adalah sejenis puisi lama yang dilisankan dan biasanya menggunakan nada atau lagu. Pantun terdiri dari unsur-unsur kalimat berjumlah empat baris dalam satu bait, yang bersajak (a-b-a-b). Biasanya barisan pertama dan barisan kedua adalah sampiran, baris ketiga dan keempat merupakan isi. Penelitian ini bertujuan untuk menguji keefektifan sebuah inovasi pembelajaran pantun berbasis kearifan lokal yakni dengan ,menggunakan kamus persajakan. Penelitian ini dikategorikan ke dalam jenis penelitian eksperimen. Metode yang digunakan peneliti dalam penelitian ini bersipat ekperimen semu (Quasi experiment) dengan model one group pretest posttest design. Populasi penelitian ini adalah semua siswa kelas siswa kelas V SDN 331 Borongtellu tahun pelajaran 2020/2021. Populasi tersebut berjumlah 30 orang sekaligus sebagai sampel penelitian. Penelitian ini mengunakan tes untuk mengetahui kemampuan menulispantun siswa Tes diberikan sebanyak dua kali yaitu pra tindakan dan pascatindakan. Data dalam penelitian inidianalisis dengan menggunakan teknik statistik inferensial atas rancangan analisis, regresi linear sederhana. Berdasarkan hasil penelitian ini dapat disimpulkan bahwa tingkat hasil belajar menulis pantun siswa kelas V SD Negeri 331 Borongtellu menggunakan teknik konvensional adalah rata-rata 67,74 dalam rentangan nilai 10-10o dengan kategori sedang. setelah diberikan perlakuan dengan menggunakan kamus rima dan berpikir lateral maka hasil belajar siswarata-rata 79,33 dalam rentangan nilai 10-100 dengan kategori tinggi. Dengan demikian penggunaan kamus rima dan berpikir lateral efektif dalam meningkatkan hasil menulis belajar pantun berbasis kearifan lokal pada siswa kelas V SD Negeri 331 Borongtellu, karena nilai t hitung/empiris lebih besar daripada nilai t tabel/teoretis (14,27>1,6709).
\end{abstract}

\section{Kata Kunci}

pantun, kamus rima, kearifan lokal 


\section{A. PENDAhUluan}

Salah satu materi pelajaran sastra Indonesia adalah menulis dan membaca pantun. Pantun sebagai bagian dari budaya sastra diupayakan untuk dilestarikan melalui proses belajar di sekolah. Pantun perlu dilestarikan karena mempunyai nilainilai etik pergaulan yang luhur dan nilai-nilai estetik yang mengagumkan. Agni dan Binar (2013) Satu isi pantun dapat berpasangan dengan bermacammacam sampiran, karena pada prosesnya sampiran pantun akan terpikirkan dari eksplorasi terhadap objek Selain itu, berpikir lateral untuk mengefektifkan proses penulisan pantun mahasiswa dibantu dengan media kamus rima atau daftar kosakata yang memiliki persajakan pada suku terakhir. Alfansyah (2017) untuk merangsang imajinasi dalam membuat sampiran pantun. Demikian halnya untuk memudahkan dan memperkaya perbendaharaan kata bersajak sama dengan sampiran pantun maka dilatihkan pula membuat dan menggunakan daftar kata yang memudahkan membuat isi pantun yang berbasis kearifan lokal.

Hasil penelitian mengenai teknik pembelajaran menulis pantun sudah banyak dilakukan, di antaranya oleh Hermawan (2013) yang menunjukkan media kartu warna dapat meningkatkan keterampilan menulis pantun anak melalui pendekatan kontekstual pada siswa kelas IVB SDN Sampangan or Semarang. Hasil senada ditemukan oleh Heriani (2014) yang menyimpulkan adanya keefektifan model Think Pair and Share dalm pembelajaran menulis pantun di kelas IV SD Negeri 7 Jeumpa. Demikian pula oleh Qomariyah (2010) dalam penerapan metode pembelajaran TTW dapats meningkatkan keterampilan / aktivitas guru dalam mengelolah pembelajaran. Demikian halnya hasil penelitian Wartik (2017) menunjukkan efektivitas pendekatan pembelajaran contextual teaching And Learning (CTL) dalam pembelajaran pantun pada siswa kelas IV Sekolah Dasar Negeri 24 Air Saleh.

Semua penelitian di atas prinsipnya menggunakan alat untuk merangsang anak dalam merumuskan unsur isi maupun sampiran pantun, Berbeda dengan gagasan yang telah penulis lakukan untuk membuktikan efektivitas penggunaan media kartu rima dalam menulis pantun berbasis kearifan lokal. Nilai kebaruan dari penelitian ini adalah karena adanya unsur kearifan lokal yang diintegrasikan dalam penulisan pantun sehingga siswa lebih paham akan materi yang ditulisnya. Selain itu penggunaan media kartu rima yang disusun oleh peneliti dapat memudahkan siswa dalam membuat pantun, baik pada unsur sampiran maupun unsur isi pantun itu sendiri.

\section{B. METODE PENELITIAN Jenis Penelitian}

Penelitian ini dikategorikan ke dalam jenis penelitian eksperimen. Metode yang digunakan peneliti dalam penelitian ini bersipat ekperimen semu (Quasi experiment) dengan model one group pretest posttest design.

Berikut variabel-variabel yang ada di dalam penelitian ini:

Variabel independen (bebas) pada penelitian ini adalah kamus rima sebagai media pembelajaran.

Variabel dependen (variabel terikat) pada penelitian ini adalah hasil belajar menulis pantun.

Populasi penelitian ini adalah semua siswa kelas siswa kelas V SD Negeri 331 Borongtellu tahun pelajaran 
2020/2021. Populasi tersebut berjumlah 30 orang sekaligus sebagai sampel penelitian

Penelitian ini mengunakan tes untuk mengetahui kemampuan menulis pantun Tes diberikan sebanyak dua kali yaitu pra tindakan dan pasca tindakan. Data dalam penelitian ini dianalisis dengan menggunakan teknik statistik inferensial atas rancangan analisis, regresi linear sederhana yaitu dengan rumus:

$\mathrm{Y}^{\prime}=\mathrm{a}+\mathrm{bX}$

\section{Keterangan:}

Y'=hasil belajar menulis pantun (Variabel dependen nilai yang diprediksikan)

$\mathrm{X}_{\mathbf{l}}=$ Kamus rima (Variabel independen) $\mathrm{a}=$ Konstanta (nilai Y' apabila $\mathrm{X}=\mathrm{o}$ )

$\mathrm{B}=$ Koefisien regresi (nilai peningkatan ataupun penurunan)
Analisis di atas menggunakan bantuan analisis computer aplikasi dengan program Add InsAnalysis Tool Pakof Excel

\section{HASIL DAN PEMBAHASAN Hasil Penelitian}

Adapun data yang dianalisis adalah hasil siswa kelompok eksperimen (X) dan hasil tes menulis pantun siswa kelompok kontrol (Y). Hasil analisis data tersebut terbagi dalam beberapa macam, yaitu skor kemampuan menulis pantun menggunakan eksplorasi teks, kamus rima, hasil pembelajaran menulis pantun menggunakan metode konvensional, dan data perbandingan atau hasil uji "t" dari kedua data tersebut, serta pengujian hipotesis. Untuk lebih jelasnya diuraikan sebagai berikut.

Tabel 1. Data tingkat hasil belajar menulis pantun siswa kelas V SD Negeri 331 Borongtellu menggunakan teknik konvensional

\begin{tabular}{cccc}
\hline NO & NILAI & F & N X F \\
\hline 1 & 100 & 0 & 0 \\
\hline 2 & 90 & 0 & 0 \\
\hline 3 & 80 & 8 & 640 \\
\hline 4 & 70 & 12 & 840 \\
\hline 5 & 60 & 7 & 420 \\
\hline 6 & 50 & 4 & 200 \\
\hline 7 & 40 & 0 & 0 \\
\hline 8 & 30 & 0 & 0 \\
\hline 9 & 20 & 0 & 0 \\
\hline 10 & 10 & 0 & 2100 \\
\hline
\end{tabular}

Sumber: hasil olahdata penelitian

Berdasarkan hasil analisis data di atas dapat diketahui:

$\mathrm{N}=30$

FN $\quad 2100$

Dengan demikian skor rata-rata yaitu:

$$
\begin{aligned}
\text { Rerata } & =\quad \mathrm{F} / \mathrm{N} \\
& =2100 / 30 \\
& =67,74
\end{aligned}
$$

Berdasarkan data di atas dapat diketahui bahwa, rata-rata nilai hasil 
belajar menulis pantun siswa kelas $\mathrm{V}$ SD Negeri $331 \quad$ Borongtellu menggunakan teknik konvensional (Kelas kontrol) adalah 67,74 dalam rentangan nilai 10-100. Selain itu, berdasarkan hasil analisis data mentah terlihat bahwa nilai perolehan tertinggi adalah 8o dari nilai maksimun 100 sebanyak satu orang. Sedangkan skor terendah adalah 54 yang diperoleh oleh satu orang. Jumlah seluruh nilai seluruh siswa yaitu 2100, sehingga ratarata skor perolehan siswa adalah 67,74.

Tabel 2. kategori nilai dikonversi pada pedoman penilaian sekolah dasar

\begin{tabular}{ccc}
\hline Konversi nilai akhir (10-100) & Kategori & Frekuensi \\
\hline $86-100$ & sangat tinggi & o \\
\hline $71^{-} 85$ & Tinggi & 8 \\
\hline $56-70$ & Sedang & 18 \\
\hline $41-55$ & Rendah & 5 \\
\hline $0-40$ & Sangat rendah & o \\
\hline
\end{tabular}

Berdasarkan tabel di atas, maka dapat dinyatakan bahwa hasil belajar menulis pantun siswakelas V SD Negeri 331 Borongtellu menggunakan teknik konvensional (kelas kontrol) berada
(Depdikbud, 2013:68)

pada kategori sedang. Selanjutnya dibandingkan dengan kelas eksperimen yang diajar dengan menggunakan kamus rima dengan berpikir lateral maka hasilnya adalah sebagai berikut.

Tabel 3. Data tingkat hasil belajar menulis pantun siswa kelas V SD Negeri 331 Borongtellu menggunakan media kamus rima (kelas eksperimen)

\begin{tabular}{cccc}
\hline NO & NILAI & F & N X F \\
\hline 1 & 100 & 0 & 0 \\
\hline 2 & 90 & 9 & 810 \\
\hline 3 & 80 & 17 & 1360 \\
\hline 4 & 70 & 4 & 210 \\
\hline 5 & 60 & 0 & 0 \\
\hline 6 & 50 & 0 & 0 \\
\hline 7 & 40 & 0 & 0 \\
\hline 8 & 30 & 0 & 0 \\
\hline 9 & 20 & 0 & 0 \\
\hline 10 & 10 & 0 & 0 \\
\hline & JUMLAH & 30 & 2380 \\
\hline
\end{tabular}

Berdasarkan hasil analisis data di atas dapat diketahui:

$\mathrm{N}=30$

$\mathrm{FN}=2380$

Dengan demikian skor rata-rata yaitu:

Rerata $=\mathrm{F} / \mathrm{N}$
Sumber: hasil olahdata penelitian

$$
\begin{aligned}
& =2380 / 30 \\
& =79,33
\end{aligned}
$$

Berdasarkan data di atas dapat diketahuia bahwa, rata-rata nilai hasil belajar menulis pantun berbasis 
kearifan lokal siswa kelas V SD Negeri 331 Borongtellu menggunakan kamus rima dan berpikir lateral (kelas eksperimen) adalah 79,33 dalam rentangan nilai 10-100. Selain itu, berdasarkan hasil analisis data mentah terlihat bahwa nilai perolehan tertinggi adalah 90 dari nilai maksimun 100 sebanyak tiga orang. Sedangkan skor terendah adalah 65 yang diperoleh oleh satu orang. Jumlah seluruh skor seluruh siswa yaitu 2380, sehingga ratarata skor perolehan siswa adalah $79 \cdot 33$.

Tabel 4. Kategori nilai dikonversi pada pedoman penilaian sekolah dasar untuk menentukan kategorisasi

\begin{tabular}{ccc}
\hline Konversi nilai akhir (10-100) & Kategori & Frekuensi \\
\hline $86-100$ & sangat tinggi & 2 \\
\hline $71-85$ & Tinggi & 23 \\
\hline $56-70$ & Sedang & 5 \\
\hline $41-55$ & Rendah & o \\
\hline $0-40$ & Sangat rendah & o \\
\hline
\end{tabular}

(Depdikbud, 2013:68)

Berdasarkan tabel di atas, maka dapat dinyatakan bahwa hasil belajar menulis pantun siswa hasil belajar menulis pantun berbasis kearifan lokal siswa Kelas V SD Negeri 331 Borongtellu menggunakan kamus rima, dan berpikir lateral berada pada kategori tinggi.
Untuk menentukan keefektifan penggunaan kamus rima dengan berpikir lateral dalam pembelajaran menulis pantun berbasis kearifan lokal siswa Kelas V SD Negeri 331 Borongtellu maka data dari kelompok ekperimen dan kelompok kontrol dianalisis dengan menggunakan tabel kerja sebagai berikut.

Tabel 5. Tabel kerja Uji t

\begin{tabular}{ccccc}
\hline No & $\mathrm{X}$ & $\mathrm{X}^{2}$ & $\mathrm{Y}$ & $\mathrm{Y}^{2}$ \\
\hline 1 & 17 & 289 & 11 & 121 \\
\hline 2 & 17 & 289 & 10 & 100 \\
\hline 3 & 18 & 324 & 14 & 196 \\
\hline 4 & 16 & 256 & 15 & 225 \\
\hline 5 & 18 & 324 & 16 & 256 \\
\hline 6 & 16 & 256 & 13 & 169 \\
\hline 7 & 17 & 289 & 10 & 100 \\
\hline 8 & 15 & 225 & 10 & 100 \\
\hline 9 & 15 & 225 & 15 & 225 \\
\hline 10 & 14 & 196 & 15 & 225 \\
\hline 11 & 15 & 225 & 14 & 196 \\
\hline 12 & 16 & 256 & 15 & 225 \\
\hline 13 & 13 & 169 & 16 & 256 \\
\hline 14 & 15 & 225 & 13 & 169 \\
\hline
\end{tabular}




\begin{tabular}{ccccc}
\hline 15 & 15 & 225 & 12 & 144 \\
\hline 16 & 16 & 256 & 11 & 121 \\
\hline 17 & 17 & 289 & 13 & 169 \\
\hline 18 & 17 & 289 & 12 & 144 \\
\hline 19 & 16 & 256 & 14 & 196 \\
\hline 20 & 18 & 324 & 14 & 196 \\
\hline 21 & 16 & 256 & 14 & 196 \\
\hline 22 & 17 & 289 & 15 & 225 \\
\hline 23 & 15 & 225 & 16 & 256 \\
\hline 24 & 15 & 225 & 13 & 169 \\
\hline 25 & 14 & 196 & 12 & 144 \\
\hline 26 & 15 & 225 & 11 & 121 \\
\hline 27 & 16 & 256 & 13 & 169 \\
\hline 28 & 15 & 225 & 12 & 144 \\
\hline 29 & 14 & 196 & 14 & 196 \\
\hline 30 & 15 & 225 & 14 & 81 \\
\hline 31 & 0 & 0 & 9 & 5430 \\
\hline Jumlah & 473 & 7505 & 406 & \\
\hline
\end{tabular}

Selanjutnya dianalisis dengan langkah sebagai berikut.

$$
\begin{aligned}
\text { Mx } & =\mathrm{Y} / \mathrm{n} 1 \\
\mathrm{Mx} & =473 / 30 \\
& =15,77 \\
\mathrm{My} & =\mathrm{Y} / \mathrm{n} 1 \\
\mathrm{My} & =406 / 31 \\
& =13,10 \\
\mathrm{SSx} & =\sum \mathrm{x}^{2}-\left(\sum \mathrm{x}^{2}\right) / \mathrm{n} 1 \\
\mathrm{SSx} & =7505^{-}(473) \mathrm{x}(473) / 30 \\
& =47,37 \\
\mathrm{SSy} & =\sum \mathrm{y}^{2}-\left(\sum \mathrm{y}^{2}\right) / \mathrm{n} 1 \\
\mathrm{SSy} & =5430-(406) \mathrm{x}(406) / 31 \\
& =112,71
\end{aligned}
$$

\section{PEMBAHASAN}

Berdasarkan dari data dalam penelitian, dapat dijelaskan bahwa hasil belajar menulis pantun berbasis kearifan lokal siswa kelas V SD Negeri 331 Borongtellu menggunakan kamus rima dengan berpikir lateraladalah 79,33 dalam rentangan nilai 10-100. Jika dikaitkan dengan klasifikasi penilaian, maka klasifikasi hasil belajar dinyatakan bahwa hasil belajar menulis pantun berbasis kearifan lokal siswa kelas V SD Negeri 331 Borongtellu menggunakan kamus rima dengan berpikir lateral berada pada kategori tinggi. Selain itu, data penelitian dapat dijelaskan bahwa tingkat hasil belajar menulis pantun berbasis kearifan lokal siswa kelas V SD Negeri 331 Borongtellu menggunakan teknik konvensional adalah 67,74 dalam rentangan nilai 10-100. Jika dikaitkan dengan klasifikasi hasil belajar maka dapat dinyatakan bahwa hasil belajar menulis pantun berbasis kearifan lokal siswa kelas V SD Negeri 331 Borongtellu menggunakan teknik konvensional masih berada pada kategori sedang.

Sementara itu, data pada hasil analisis keefektifan dalam uji $t$, menunjukkan nilai hitung /empiris $\left(\mathrm{t}_{\mathrm{a}}\right): \quad 14, \quad 27$ sedangkan nilai tabel/teoretis $\left(t_{t}\right)$ : 1,6709 pada taraf sigrifikansi $95 \%$, sehingga dinyatakan 
bahwa nilai $\mathrm{t}$ hitung/empiris lebih besar daripada nilai $t$ tabel/teoretis $(14,27>1,6709)$ yang berarti eksplorasi teks, kamus rima, dan berpikir lateral efektif dalam meningkatkan hasil menulis pantun berbasis kearifan lokal kelas V SD Negeri 331 Borongtellu pada taraf kepercayaan $95 \%$.

Berdasarkan hasil penelitian ini dapat dipahami bahwa salah satu alternatif mengefektifkan pembelajaran menulis pantun berbasis kearifan lokal di sekolah dasar adalah menggunakan kamus rima dengan berpikir lateral. Hal ini telah dibuktikan dengan ujicoba pada siswa kelas kelas V SD Negeri 331 Borongtellu yang menunjukkan hasil yang efektif.

Akadijah (2010) Pembelajaran menulis pantun yang selama ini dianggap sulit bagi siswa dapat dilatihkan dengan menggunakan kamus rima dengan berpikir lateral untuk menghasilkan pantun berbasis kearifan lokal. Hal ini karena kamus rimadapat memicu siswa dalam membuat sampiran pantun yang memiliki muatan subtansi dalam kurikulum secara terpadu. Selain itu, kesulitan dalam menentukan ini dibantu dengan kamus rima yang menuntun siswa dalam mengembangkan isi melalui daftar nilai-nilai karakter yang sejalan dengan kearifan lokal dan dampaknya.

Sedangkan untuk mempercepat proses semua itu, dibantu dengan teknik berpikr lateral. Hasil penelitian ini sesuai dengan konsep yang dikemukakan oleh Feedburner (2013) bahwa teknik eksplorasi dalam belajar memicu anak mengembangkan kecerdasar berpikir dan melejitkan imajinasi siswa. Selain itu, berpikir lateralatau berpikir pengarah perhatian adalah istilah yang diberikan oleh Bono, (2013) dalam sebuah pendekatan berpikir yakni Cognitif Research Trust (CoRT). Kegiatan berpikir Cognitif Research Trust merupakan sebuah label baru bagi berpikir. Arif (2011) Cognitif Research Trust sebagai pendekatan pengajaran berpikir yang sangat terkenal sebagai sebuah program yang disajikan oleh Edward de Bono Foundation Inggris yang memungkinkan para guru untuk meningkatkan kinerja kreativitas meraka.

\section{E. SIMPULAN}

Berdasarkan hasil penelitian ini dapat disimpulkan bahwa tkat hasil belajar menulis pantun berbasis kearifan lokal siswa kelas V SD Negeri 331 Borongtellu menggunakan kamus rima dengan berpikir lateraladalah rata-rata 79,33 dalam rentangan nilai 10-100 dengan kategori tinggi.Tingkat hasil belajar menulis pantun berbasis kearifan lokal siswa kelas V SD Negeri 331 Borongtellu menggunakan teknik konvensional adalah rata-rata 67,74 dalam rentangan nilai 10-100 dengan kategori sedang. Hasil penelitian ini membuktikan bahwa penggunaan kamus rima dengan berpikir lateral efektif dalam meningkatkan hasil belajar menulis pantun berbasis kearifan lokal siswa kelas V SD Negeri 331 Borongtellu, karena nilai $t$ hitung/empiris lebih besar daripada nilai t tabel/teoretis $(14,27>1,6709)$.

\section{DAFTAR PUSTAKA}

Agni dan Binar. 2013. Pantun, Puisi, Majas, Peribahasa, Kata Mutiara. Jakarta : Hi-Fest Publishing Akhadiah. 2010. Pembinaan Kemampuan Menulis Bahasa Indonesia Jakarta : Erlangga Alfansyah, 2017. Pembelajaran Sastra Dewasa Ini. Jakarta: Gema Press 
Arif. 2011. Indonesia dalam Pantun. Makassar: Pustaka Refleksi

Bono. 2013. "Kearifan BudayaLokal Perekat Identitas Bangsa." Jurnal Bakti Saraswati. Diakses Pada Hari Minggu 20 Juli 2019. Pukul oo.oo WIB $05 \quad$ (o1): 9-16. https://doi.org/10.1007/s11104-0o89614-4.

Feedburner. 2015. Pembelajaran Sastra di Sekolah Dasar. Jakarta: Gema Media

Nurgiantoro, Burhan. 2011. Penilaian dalam Pengajaran Bahasa dan Sastra.Yogyakarta: BPEE.

Qomariah. 2010. Media dalam menulis pantun di SD. Solo: Matahati

Rudy, Achmad. 2012. Pembelajaran Sastra di SD. Jakarta: Insan Press.

Sugiyono, 2011. Penelitian Pendidikan . Bandung:Angkasa

Wartik. 2017. "ANALISIS PENGGUNAAN PANTUN DALAM BUDAYA MASYARAKAT GAYO LUES oleh" 4: 39-52.

Suwitaningrum, Retno. 2010. Buku Pintar Peribahasa Pantun dan Puisi. Surakarta: Putra Mand 